\title{
Correction to: Values of love: two forms of infinity characteristic of human persons
}

\section{Sara Heinämaa ${ }^{1}$}

Published online: 10 February 2020

(C) Springer Nature B.V. 2020

\section{Correction to: Phenomenology and the Cognitive Sciences https://doi.org/10.1007/s11097-019-09653-2}

The original version of this article unfortunately contains incorrect article title and incorrect data in the body text.

The corrected article title is presented in this correction article.

Abstract, 3rd line from below: Delete the term "that" after the term "argue" SHOULD READ:

...I argue Husserl's concept of love...

Introductory section, 3rd paragraph from above, 9th line from above: Substitute number " 27 " for number " 28 ".

SHOULD READ:

...Aufsätze und Vorträge (Hua27)...

Introductory section, 2nd footnote: Add letter "s" at the end of the word "course". SHOULD READ:

...the lecture courses on axiolology...

Section 1, footnote 6: delete the plural ending "-es" in the word "consciousnesses". SHOULD READ:

...real and actual consciousness...

Section 2, footnote 8: Add letter "e" before letter " $r$ " in the word "Intresseneinstellung".

SHOULD READ:

The online version of the original article can be found at https://doi.org/10.1007/s11097-019-09653-2

Sara Heinämaa

sara.heinamaa@jyu.fi

1 Academy of Finland; Department of Social Sciences and Philosophy, University of Jyväskylä, P.O. Box 35, 40014 Jyväskylä, Finland 
...(Interesseneinstellung...

Section 2, 12th paragraph from above, 2nd sentence from above: The word "sentimentalize" is wrongly syllabized. The correct syllabification is "sentimenta-lize" (and not "sentimental-ize").

SHOULD READ:

...would idealize and sentimenta-lize the case...

Section 3, footnote 21: Add letter "h" before letter " $r$ " in the name "Vonger".

SHOULD READ:

... Sowa and Vongehr

REFERENCES SECTION:

Husserl, E. (Hua3): Add letter "e" after letter "i" in the name "Bimel".

SHOULD BE: ... Ed. W. Biemel...

Husserl, E. (Hua4): Add letter "e" after letter "i" in the name "Bimel".

SHOULD BE: ... Ed. W. Biemel...

Husserl, E. (HuaMat9): Substitute word "Materialien" for the word "Materien".

SHOULD BE: ...Husserliana Materialien IX...

Husserl, E. ([1939] 1985): Delete letter "s" in the name "Churschill".

SHOULD BE: ...Trans. J.S. Churchill...

Sowa, R. and T. Vonger (2013): Add letter "h" before letter "r" in the name "Vonger".

SHOULD BE: ... Sowa, R. and T. Vongehr

Urban, P. (2016): Substitute word "Gesamtwerks" for word "Gesamtswerks".

SHOULD BE: ...Gesamtwerks (pp. 538-555)...

The original article has been corrected.

Publisher's note Springer Nature remains neutral with regard to jurisdictional claims in published maps and institutional affiliations. 